\title{
The red dwarf honey bee (Apis florea F.) faces the threat of extirpation in Northwest India

\author{
R.C. Sihag
}

Laboratory of Animal Behavior and Simulated Ecology,

Department of Zoology, College of Basic Sciences and Humanities,

CCS Haryana Agricultural University, Hisar-125004, India

*Corresponding author E-mail: rcsihag@hau.ac.in; rcsihag@gmail.com

Received: 15.02.2021. Accepted: 15.03.2021.

\begin{abstract}
Pollination is one of the essential ecosystem services. In recent years, a severe global pollinator decline has been the prime concern of pollination scientists and agriculturalists. The red dwarf honey bee (Apis florea F.) is an important pollinator of the semi-arid to tropical environments of several parts of Asia. The actual status of the colony numbers and foraging populations of this honey bee are not known. In this article, I examined the status of these parameters of this honey bee in Northwest India. I conducted monthly surveys and counted the total number of colonies of the red dwarf honey bee present at the main campus of CCS Haryana Agricultural University, Hisar (India) (in about $9 \mathrm{~km}^{2}$ ) from 1984 to 2011 at an interval of three years. I also counted the number of foraging honey bees on two crops, viz. a winter-flowering crop, Raya (Brassica juncea Czern \& Coss), and a summer-flowering crop, Carrot (Daucus carota L). In 27 years, the number of colonies of this honey bee in the study area declined from $221.5 \pm 14.1$ in 1984 to $53.4 \pm 6.6$ in 2011. The foraging populations of this honey bee too declined from $31.2 \pm 0.3$ bees $/ \mathrm{m}^{2}$ to $9.2 \pm 0.2$ bees $/ \mathrm{m}^{2}$ on Carrot and from $25 \pm 0.3$ bees $/ \mathrm{m}^{2}$ to $3.3 \pm 0.2$ bees/ $\mathrm{m}^{2}$ on Raya. This honey bee exhibited a significant decline in its colony number every 6 years. Foraging bees declined significantly every three years. The colony and forager surveys revealed that the red dwarf honey bee (Apis florea F.) seemed to face the threat of extirpation (local extinction) in Northwest India. This decline in the colony numbers and the foraging populations seemed to have caused a pollination crisis in this region. The decline in the colony numbers and the foraging populations seemed to be caused by the poisoning of foraging bees due to the excessive and indiscriminate use of insecticides on the Cotton and/or Rice crops that come in blooms during the floral dearth period of this region. Considered the importance of this honey bee in the pollination of crops, I suggested that this honey bee must be vigorously protected and conserved.
\end{abstract}

Keywords: Red dwarf honey bee, Apis florea, population, pollination.

\section{Introduction}

In recent years, many ecosystem services essential for human welfare are under the threat of disruption; pollination is one such vulnerable service (Klein et al. 2006). Recent reports reveal many impending threats to the pollination service (Klein et al., 2007; Vanbergen, 2013); demonstrating global pollinator declines (Potts et al., 2010a; Powney et al., 2019), both species diversity and richness of pollinators have declined (Biesmeijer et al., 2006; Johnson, 2007; National Research Council, 2007; Potts et al., 2010a; Garibaldi et al. 2010; Carvalheiro et al.,2013). Now there is clear evidence of recent declines in both wild (Kremen et al., 2002, 2004; Kluser and Peduzzi, 2007; Goulson et al., 2008; Grixti, 2009; Williams and Osborne, 2009) and domesticated pollinators, including honey bees (Kraus and Page, 1995; Schneider et al., 2004; Oldroyd, 2007; Van Engelsdorp et al., 2008; Neumann, 2010; Potts et al., 2010b; Breeze et al., 2011), and parallel declines in the plants that rely upon them (Biesmeijer, 2006). Some researchers have described the nature and extent of reported declines (Potts et al., 2010a; Goulson et al., 2015) and reviewed the potential drivers of pollinator loss, including habitat loss (Banaszak, 1992; Steffan-Dewenter et al., 2002) and fragmentation (Tonhasca et al., 2002), agrochemicals (Kevan, 1975; Brittain et al., 2010), pathogens (Cameron, 2011), alien species, climate change (Le Conte and Navajas, 2008; Hegland et al., 2009) and the interactions between them (Kearns et al., 1998; Pauw, 2007; Burkle et al., 2013). Pollinator declines have been reported to result in loss of pollination services which have significant negative ecological and economic impacts that could significantly affect the maintenance of wild plant diversity, more comprehensive ecosystem stability, crop production, food security, and human welfare (Allen-Wardell et al., 1998; Kremen and Ricketts, 2000; Richards, 2001; Kremen et al., 2002; Westerkamp and Gottsberger, 2002; Steffan-Dewenter et al., 2005; Klein et al., 2007).

In northwest India, Apis cerana and Apis indica are absent, and Apis mellifera was introduced only in the early 1980s.The crop growers have to rely on two wild honey bee species (viz. Apis dorsata and Apis florea) to pollinate their crops. However, this region's recent reports reveal that the colonies of the giant honey bee (Apis dorsata) are declining in this region (Sihag, 2014). Therefore, the red dwarf honey bee (Apis florea) alone remains to be the most dependable pollinator of this region's crops (Sihag, 2019a). The latter contention is strongly supported by the available reports showing the red dwarf honey bee (Apis florea F.) as the most abundant and dominant pollinator of many crops of this region; for example, many oilseeds, vegetable, fruit, and condiment crop plants (Sihag, 1986, 2000, 2018, 2019a). These crops are grown more extensively in this region with the introduction of canals.

Consequently, the whole region has also witnessed the introduction of pesticides usage for crop protection (Alagh, 1988; Subhash et al., 2017; Lakshmi Priya, 2017). This seemed to have led to a complete change in this region's ecology and environment, adversely affecting non-target organisms' lives (Plumer, 2014; Karen, 2018); the red dwarf honey bee (Apis florea) should be no exception. The exact information on this honey bee's colony status in the region's changing environment was not yet known. I report here a highly dire state of colony number of this honey bee which seems to head towards extirpation. 


\section{Methods}

I conducted this study at the main campus (in about $9 \mathrm{~km}^{2}$ ) of CCS Haryana Agricultural University, Hisar (Haryana, India). In this region, honey bees release swarms in February-March, from mid-May to August is the dearth period (Sihag, 1990) and August to September also mark the period of insecticide sprays on the cotton crop (Toppo, 2019). From November to February is the pollen and nectar flow and colony buildup period (Sihag, 1990). In the study area, the red dwarf honey bee makes nests in the hedges and the bushes along the roads and the water channels (Fig. 1 and 2). The colonies of this honey bee make local migrations and keep visiting the flowers of several crops that are grown in this region (Oldroyd and Wongsiri, 2006; Hepburn and Radloff, 2011; Sihag, 2019a)

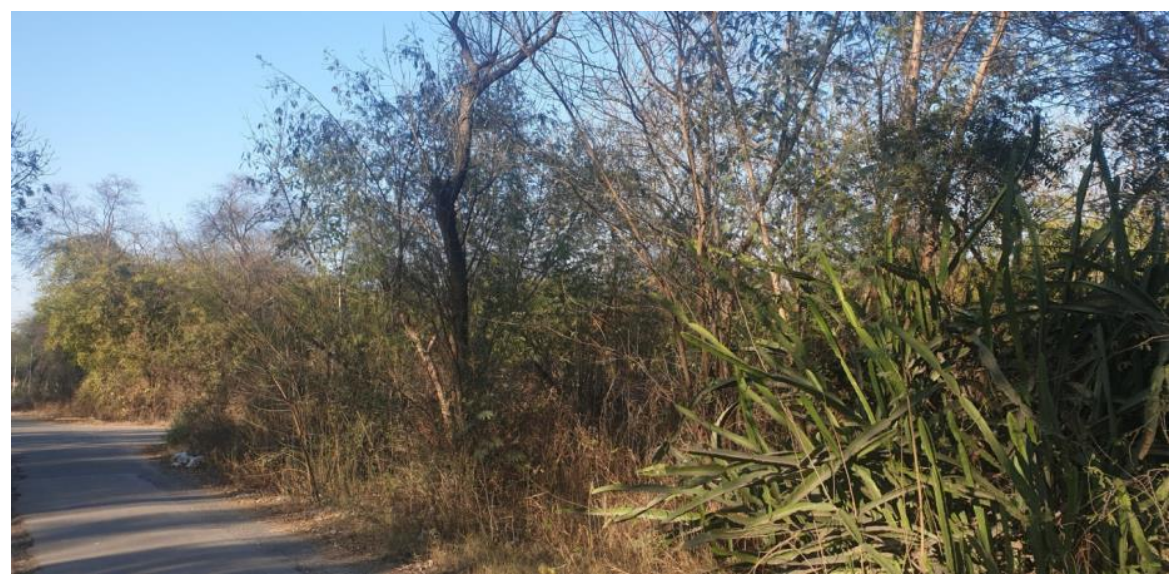

Fig. 1. Bushes along the road of the study site where A. florea make nest.

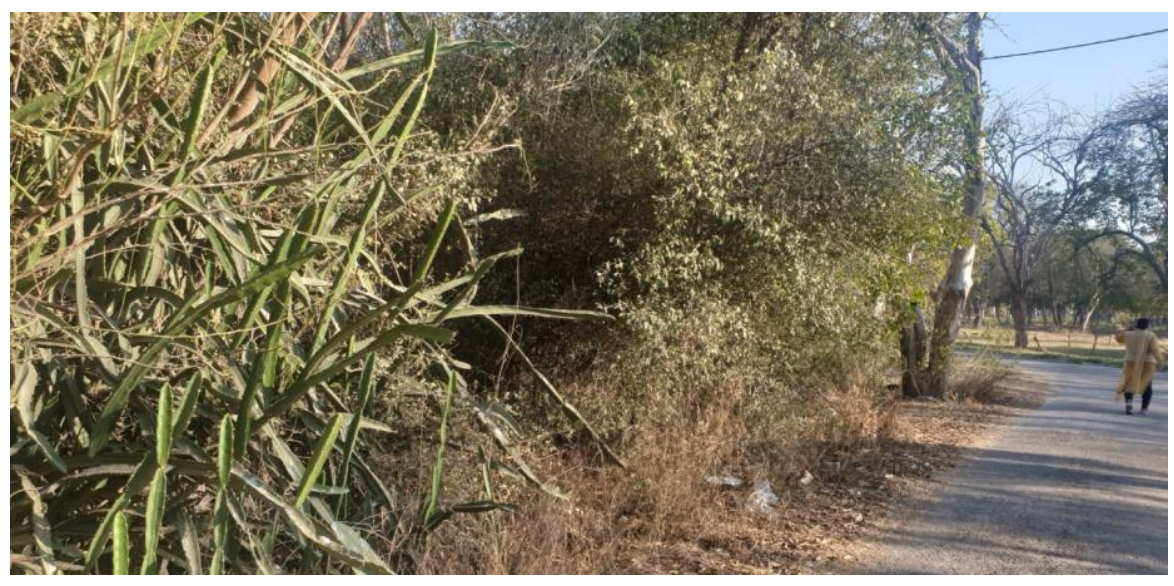

Fig. 2. Bushes in the hedge along the road of the study site where A. florea make nest.

\section{Survey of the number of colonies of the red dwarf honey bee}

To make surveys on the number of colonies of the red dwarf honey bee (Apis florea F.) in the study area, I counted colonies of this honey bee in the last week of each month and sunny days, thus making 12 monthly observations in a study year. I counted all the colonies in the entire study area present in the hedges alongside the roads/water channels while moving in a straight line from one end to the other end of the road/water channel. I repeated the surveys at three-year intervals from 1984 to 2011 , thus making ten observation years. Thus, in total, I made 120 observations on the colony number of this honey bee during the entire period of this study (12 months $\times$ ten years).

\section{Survey of the foraging populations of the red dwarf honey bee}

I recorded the foraging populations of the red dwarf honey bee on two crops, viz. a winter crop, Raya (Brassica juncea Czern \& Coss) (Fig. 3), and an early summer crop, carrot (Daucus carota L.) (Fig. 4). Both these crops are grown for seed production at the Research Farm of Haryana Agricultural University. Raya comes in blooms in this region during the winter months (December through mid-February) whereas carrot flowers in early summer (March/April).

I randomly selected five plots of $1 \times 1 \mathrm{~m}^{2}$ in the crop area during the crops' peak flowering and recorded the observations on sunny days at noon on the Raya plots and $1100 \mathrm{~h}$ on the Carrot plots. I recorded the instant number of foraging bees present in $1 \times 1 \mathrm{~m}^{2}$ areas on five plots and repeated weekly intervals on five days (total $5 \times 5=25$ observations). I repeated these observations threeyear intervals from 1984 to 2011. All the original data are available in the repository: https://github.com/EDIorg/MetadataTemplates/compare/master...sihagrc:patch-1

I used OPSTAT (2018a) for testing the statistical significance of data. For testing the effect of years and months on the number of colonies, I processed the data for one-factor analysis (OPSTAT, 2018b). Likewise, for the effect of years and plots on the number of foragers, I processed the data for two-factor analysis (OPSTAT, 2018c) However, for the comparison of the 'number of foragers on Raya and Carrot plots' I processed the data for one-factor analysis (OPSTAT, 2018b).

In all these cases, I used the Duncan Multiple Range Test as a post hoc test to compare the individual means. I derived yearly means of colony numbers from the 12 monthly observations and the monthly means from the 10 yearly observations. Likewise, for comparing between means of foragers in different years, I derived the latter from 25 observations ( 5 plots $\times$ each plot having five 
observations). To compare between means of foragers in various plots, I derived the latter from 50 observations (10 years $\times$ five observations in each plot). I derived C.D. (critical difference) for each analysis and calculated differences between individual means of a parameter. If the difference between any two means was more than the calculated value of C.D., I considered this difference as statistically significant, and the two means differed significantly (Snedecor and Cochran, 1967; OPSTAT, 2018a,b,c).

I derived correlations between numbers of colonies and the foragers and tested these with a simple T-test (Snedecor and Cochran, 1967).

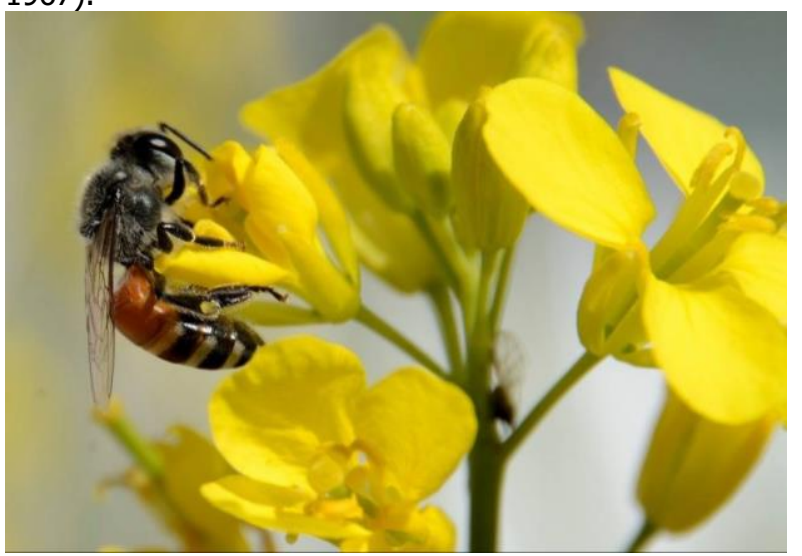

Fig. 3. Red dwarf honey bee (Apis florea) foraging on Raya (Brassica juncea) flowers.

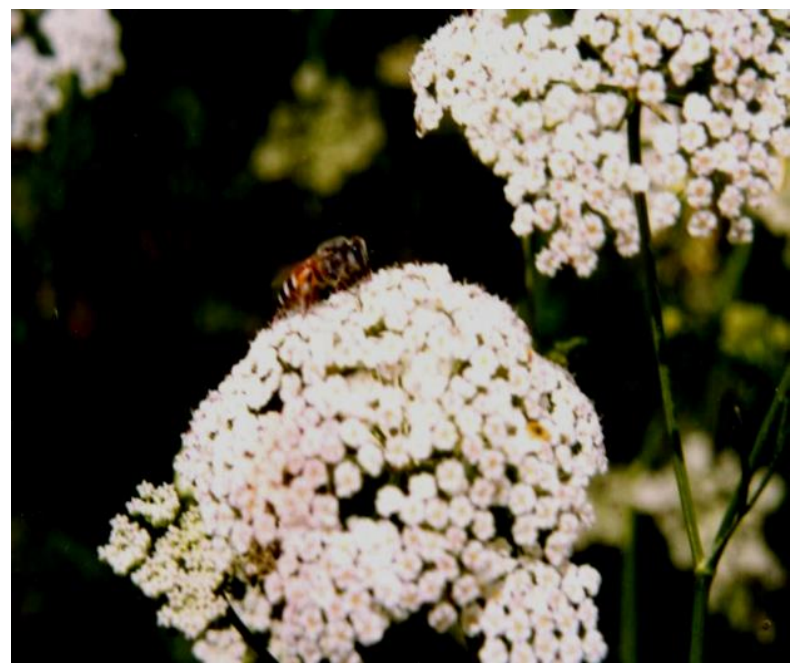

Fig. 4. Red dwarf honey bee (Apis florea) foraging on carrot (Daucus carota) flowers.

\section{Results}

\section{The pattern of colony numbers of the red dwarf honey bee}

The red dwarf honey bee colonies showed a steep decline in their numbers in this region from 1984 to 2011 (Fig. 5). In 1984 there were $221.5 \pm 14.1$ (mean $\pm S E, n=12$ ) colonies of this honey bee in the study area. The number of colonies remained more than

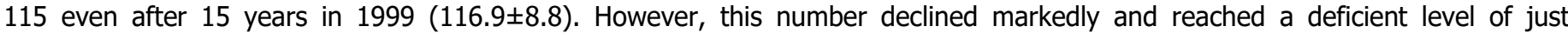
$53.4 \pm 6.6$ colonies in 2011 . This is about a 76 percent decline in the number of colonies of this honey bee in the study area in 27 years (Fig. 3). Statistically, the decline in the colonies over the years was highly significant $\left(F_{(9,110)}=32.6, \mathrm{P}<0.000001, \mathrm{ANOVA}\right.$; Table 1). The post hoc test (Duncan Multiple Range Test, Table 1) endorsed this view for 1984-1987, where a significant difference in colonies occurred; in all other consecutive (i.e., between two adjoining) 'three-year intervals', the colony declines were nonsignificant. However, after every 6-year interval, there was a significant decline in the colony numbers (Table 1). Thus, under the given conditions, since 1987, every six years lapse of time resulted in a significant decline in the colonies of the red dwarf honey bee at the place of this study.

This honey bee showed a decline of colonies even in different months as the differences were significant $(F$ (11, 108) $=3.423$, $\mathrm{P}=0.00042$, ANOVA, Table 2). The post hoc test (Duncan Multiple Range Test) revealed that the colonies of this honey bee in a year conspicuously showed four distinct periods (Table 2). The first period was the 'period of multiplication and sustenance' of the colonies from March to April. In March, the number of colonies increased due to swarming in this honey bee in this region; and all the old colonies migrated due to the infestation by the wax moth (Galleria mellonella L.) (Sihag, 2019b). All the colonies which settled in the study area in March sustained till April (Table 2). This period witnessed the maximal number of colonies in this region. 


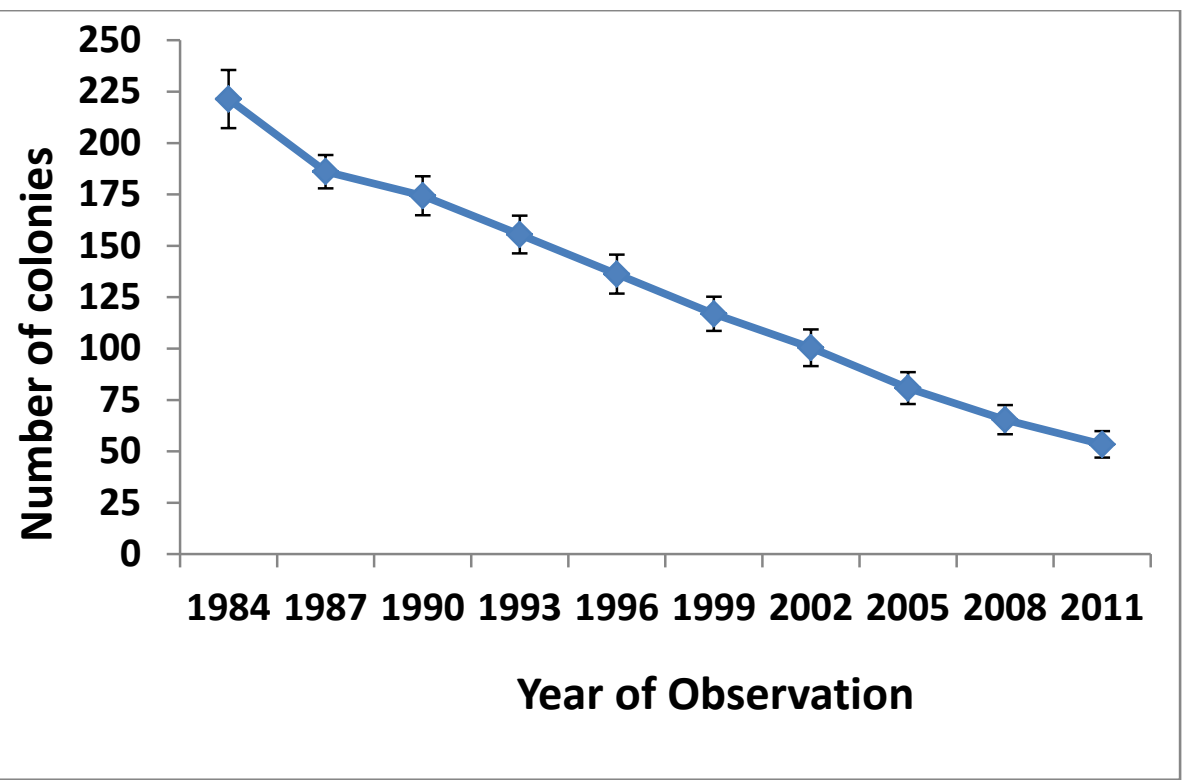

Fig. 5. Pattern of decline in the colony numbers of the red dwarf honey bee from 1984 to 2011 (vertical bars represent standard errors).

The second period spanned during May and June when the region witnessed extreme hot and dry weather. During this period, colonies declined, but this decline was not significant from the number present in March-April. The third period was extended from July to October when a significant decline in the colony numbers took place (Table 2). July to September is the monsoon period, and August and September are the months of insecticide sprays on the cotton and rice crops in this part of India. By August, the number of colonies declined significantly, and this phase of colony decline persisted till October. The fourth period spanned from November to February. During this period, this region witnessed the lowest number of colonies that persisted till February. This cycle of colony multiplication and decline has been going on year after year; the declines significantly outnumbered the multiplications. The net result has been approaching this honey bee to a stage of extirpation in this region.

Table 1. Number of colonies of the red dwarf honey bee in different years of the study period. Means with dissimilar letters differ significantly (Duncan Multiple Range Test).

\begin{tabular}{cc}
\hline Year & Mean number of colonies \\
1984 & $221.5^{\mathrm{A}}$ \\
1987 & $189.3^{\mathrm{B}}$ \\
1990 & $174.3^{\mathrm{BC}}$ \\
1993 & $155.0^{\mathrm{CD}}$ \\
1996 & $137.0^{\mathrm{DE}}$ \\
1999 & $116.9^{\mathrm{EF}}$ \\
2002 & $100.4^{\mathrm{FG}}$ \\
2005 & $80.8^{\mathrm{GH}}$ \\
2008 & $66.2^{\mathrm{HI}}$ \\
2011 & $53.4^{\mathrm{I}}$ \\
F(9, 110$)$ & 32.6 \\
Calculated & $<0.000001$ \\
p-Value & 27.3 \\
C.D. & \\
\hline
\end{tabular}

C.D. = Critical difference. If the difference between any two means is greater than C.D., this difference is statistically significant i.e. the two means differ significantly.

Table 2. Number of colonies of the red dwarf honey bee in different months of study period. Means with dissimilar letters differ significantly (Duncan Multiple Range Test).

\section{Month}

January

February

\section{Mean number of colonies}

$102.8^{\mathrm{B}}$

$102.8^{\mathrm{B}}$ 


$\begin{array}{cc}\text { March } & 180.5^{\mathrm{A}} \\ \text { April } & 180.5^{\mathrm{A}} \\ \text { May } & 169.5^{\mathrm{A}} \\ \text { June } & 154.5^{\mathrm{A}} \\ \text { July } & 132.1^{\mathrm{AB}} \\ \text { August } & 120.5^{\mathrm{AB}} \\ \text { September } & 111.7^{\mathrm{AB}} \\ \text { October } & 103.9^{\mathrm{B}} \\ \text { November } & 97.8^{\mathrm{B}} \\ \text { December } & 97.8^{\mathrm{B}} \\ \text { F }_{(11,108)} & 3.423 \\ \text { Calculated } & \\ \text { p-Value } & 0.00042 \\ \text { C.D. } & 49.9\end{array}$

\section{The pattern of foraging populations of the red dwarf honey bee}

The foraging populations of the red dwarf honey bee also showed a steep decline over this study's years (Fig. 6). The average foraging populations of this honey bee on Raya and Carrot crops were $25 \pm 0.3$ bees $/ \mathrm{m}^{2}$ and $31.2 \pm 0.3$ bees $/ \mathrm{m}^{2}$ in 1984 . These populations showed a gradual decline along the observation years and were just $3.3 \pm 0.2$ bees $/ \mathrm{m}^{2}$ and $9.2 \pm 0.2$ bees $/ \mathrm{m}^{2}$ in 2011 , respectively. This decline in foraging populations is about 88 percent on Raya and 71 percent on the carrot. Statistically, the decline in foraging populations too along the years was highly significant (for Raya: $F_{(0,200)}=578.6, \mathrm{P}=0.000001$, ANOVA, Table 3; for Carrot: $F_{(9,200)}=427.9, \mathrm{P}=0.000001$, ANOVA, Table 4). The post hoc test (Duncan Multiple Range Test, Table 1) revealed that a significant decline in the number of foraging bees occurred between all the consecutive (i.e., between two adjoining) 'year intervals' (Table 3,4). On the other hand, foraging bees on the five sampled plots of a crop were statistically similar in numbers as the differences among plots were non-significant (for Raya: $F_{(4,200)}=0.08, \mathrm{P}=0.988$, ANOVA, Table 5; for Carrot: $F_{(4,200)}=0.05$, $\mathrm{P}=0.993$, ANOVA, Table 6). Hence variation due to plots was non-significant. Interactions between year and plots too were nonsignificant (Raya: $F_{(36,200)}=.22, \mathrm{P}=1.0000$, ANOVA; Carrot: $F_{(36,200)}=0.14, \mathrm{P}=1.0000$, ANOVA) indicating that years and plots did not significantly influence (interfere with) each other in their effects on the foraging populations.

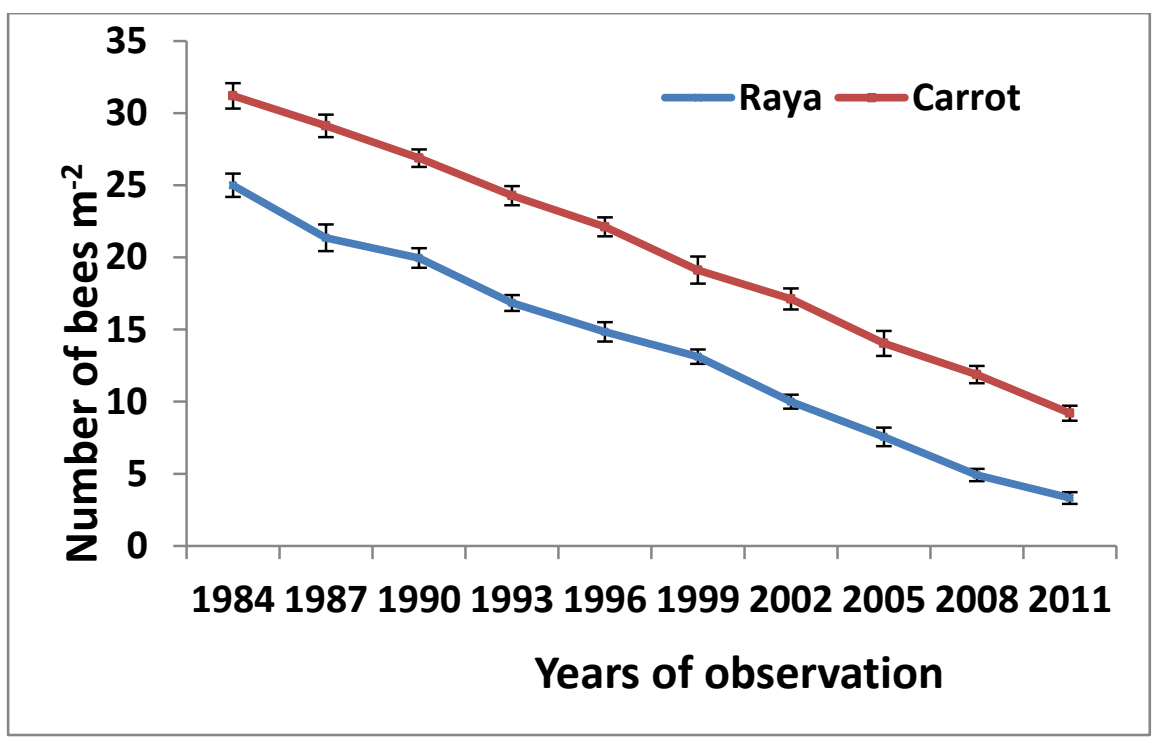

Fig. 6. Pattern of decline in the number of foraging bees (per $\mathrm{m}^{2}$ ) of the red dwarf honey bee on two crops from 1984 to 2011 (vertical bars represent standard errors).

Table 3. Number of foraging bees (per $\mathrm{m}^{2}$ ) of the red dwarf honey bee on Raya crop in different years of the study period. Means with dissimilar letters differ significantly (Duncan Multiple Range Test).

$\begin{array}{cr}\text { Year } & \text { Mean number of } \\ 1984 & 25.00^{\mathrm{A}} \\ 1987 & 21.36^{\mathrm{B}} \\ 1990 & 19.96^{\mathrm{C}}\end{array}$




\begin{tabular}{cc}
\hline 1993 & $16.84^{\mathrm{D}}$ \\
1996 & $14.84^{\mathrm{E}}$ \\
1999 & $13.12^{\mathrm{F}}$ \\
2002 & $10.00^{\mathrm{G}}$ \\
2005 & $7.56^{\mathrm{H}}$ \\
2008 & $4.92^{\mathrm{I}}$ \\
2011 & $3.32^{\mathrm{J}}$ \\
F(9, 240) & 578.627 \\
Calculated & \\
p-Value & $<.000001$ \\
C.D. & $0.841^{\mathrm{N}}$ \\
\hline
\end{tabular}

The number of foraging bees on Carrot plots was higher than that on the Raya plots (Fig. 6, Tables 5 and 6); and the difference between the two crop plots was highly significant $\left(F_{(1,498)}=112.7, \mathrm{P}<0.000001\right.$, ANOVA). Furthermore, the foraging populations on both the crop plots were directly and positively correlated with the colony numbers, as very high and significant positive correlations existed between these two parameters $\left(r_{\text {raya }}=0.99 ; r_{\text {carrot }}=0.98 ; p<0.01, T\right.$-test $)$.

Table 4. Number of foraging bees (per $\mathrm{m}^{2}$ ) of the red dwarf honey bee on Carrot crop in different years of the study period. Means with dissimilar letters differ significantly (Duncan Multiple Range Test).

\begin{tabular}{cc}
\hline Year & Mean number of bees \\
1984 & $31.20^{\mathrm{A}}$ \\
1987 & $29.12^{\mathrm{B}}$ \\
1990 & $26.88^{\mathrm{C}}$ \\
1993 & $24.28^{\mathrm{D}}$ \\
1996 & $22.12^{\mathrm{E}}$ \\
1999 & $19.12^{\mathrm{F}}$ \\
2002 & $17.12^{\mathrm{G}}$ \\
2005 & $14.0^{\mathrm{H}}$ \\
2008 & $11.8^{\mathrm{I}}$ \\
2011 & $9.20^{\mathrm{J}}$ \\
F(9,240) & 427.943 \\
Calculated & \\
p-Value & $<.000001$ \\
C.D. & 1.009 \\
\hline
\end{tabular}

Table 5. Number of foraging bees (per $\mathrm{m}^{2}$ ) of the red dwarf honey bee on different plots of Raya crop.

$\begin{array}{cc}\text { Plot } & \text { Mean number of } \\ \text { Plot } 1 & 13.78 \\ \text { Plot } 2 & 13.68 \\ \text { Plot } 3 & 13.66 \\ \text { Plot } 4 & 13.62 \\ \text { Plot } 5 & 13.72 \\ \text { F(4, 240) } & 0.082 \mathrm{NS} \\ \text { Calculated } & \\ \text { p-Value } & 0.988 \\ \text { C.D. } & \text { N.A. }\end{array}$


Table 6: Number of foraging bees (per $\mathrm{m}^{2}$ ) of the red dwarf honey bee on different plots of Carrot crop.

\begin{tabular}{cc} 
Plot & Mean number of bees \\
Plot 1 & 20.54 \\
Plot 2 & 20.42 \\
Plot 3 & 20.56 \\
Plot 4 & 20.52 \\
Plot 5 & 20.44 \\
F(4, 240) $_{\text {Calculated }}$ & 0.059 NS \\
p-Value & \\
C.D. & 0.993 \\
\hline
\end{tabular}

C.D. =Critical difference; NS= Non-significant; N.A.= Not applicable

\section{Estimated pollination losses to the crops of the northwestern region of India}

In India's northwestern region, the red dwarf honey bee is the most abundant and an important pollinator of some 35 crops (Sihag, 1986, 2000, 2018, 2019a; Table 7). Many of these crops are cross-pollinated (either self-incompatible, or show the presence of protandry or protogyny or bear unisexual flowers) and need biotic pollen vector for pollination of their flowers (Sihag, 2001).In this region, the latter crops flower during the summer months when other pollinators are not active. Loss of foraging populations of Apis florea would mean the loss of freely available pollination service to the crop growers of this region.

Table 7. Crop hosts of the red dwarf honey bee in the semi-arid environment of northwest India (adapted from Sihag, 2019a).

\section{Crop host}

Pigeon pea (Cajanus cajan (L.) Millsp.)

Toria (Brassica campestris L. var. toria)

Raya (Brassica juncea Czern. \& Coss)

Salad rocket (Eruca sativa Mill.)

Chick pea (Cicer arietinum L.)

Fenugreek (Trigonella foenum-graecum L.)

Lemon (Citrus limon (L.) Burm. f.)

Kinnow (Citrus nobilis $\times$ Citrus deliciosa)

Peach (Prunus persica) (L.) Stokes

Onion (Allium cepa L.)

Carrot (Daucus carota L.)

Sun flower (Helianthus annuus L.)

Berseem/clover (Trifolium alexandrinum L.)

Alfalfa (Medicago sativa L.)

Guava (Psidium guajava L.)

Cucurbits

Pearl millet (Pennisetum typhoides)

Cotton (Gossypium hirsutum)

Rice (Oryza sativa)

$\begin{array}{cr}\text { Flowering time } & \text { Source } \\ \text { Sep-Oct } & \mathrm{P}, \mathrm{N} \\ \text { Oct-Nov } & \mathrm{P}, \mathrm{N} \\ \text { Dec-Feb } & \mathrm{P}, \mathrm{N} \\ \text { Dec-Mar } & \mathrm{P}, \mathrm{N} \\ \text { Feb-Mar } & \mathrm{P}, \mathrm{N} \\ \text { Feb-Mar } & \mathrm{P}, \mathrm{N} \\ \text { March } & \mathrm{P}, \mathrm{N} \\ \text { March } & \mathrm{P}, \mathrm{N} \\ \text { March } & \mathrm{P}, \mathrm{N} \\ \text { Mar-Apr } & \mathrm{P}, \mathrm{N} \\ \text { Mar-April } & \mathrm{P}, \mathrm{N} \\ \text { Mar-May } & \mathrm{P}, \mathrm{N} \\ \text { Mar-May } & \mathrm{P}, \mathrm{N} \\ \text { Mar-Oct } & \mathrm{P}, \mathrm{N} \\ \text { Apr-May } & \mathrm{P}, \mathrm{N} \\ \text { Mar-Nov } & \mathrm{P}, \mathrm{N} \\ \text { May-Aug } & \mathrm{P} \\ \text { July-Sep } & \mathrm{P}, \mathrm{N} * \\ \text { Aug-Sep } & \mathrm{P} \\ & \end{array}$

$\mathrm{M}$ :major crop of the region; $\mathrm{m}$ :minor crop of the region; $\mathrm{P}=$ pollen source; $\mathrm{N}=$ nectar source; $*$ Extra-floral nectarines on the leaves; Bold letters show crops sprayed heavily with toxic insecticides.

\section{Discussion}

The red dwarf honey bee (Apis florea F.) is a natural, wild and important pollinator of many crops and wild plants of Southeast Asia to East Africa (Oldroyd and Wongsiri, 2006; Hepburn and Radloff, 2011; Sihag, 1986, 2000, 2018, 2019a). This honey bee is distributed in various habitats, such as semi-deserts, steppes, savannas and rainforests; and likewise diverse climates viz., semiarid, sub-tropical and tropical. Its distribution ranges from Southeast Asia to the Far East (Ruttner, 1988; Hepburn, 2005; Moradi and Kandemir, 2005; Moritz et al., 2010), extending to Pakistan and Afghanistan. In recent years, this honey bee has been expanding its range from its earlier distribution to Iran (Ottis, 1996), coastal areas of Southern Iraq, Oman, Yemen, Sudan (Mogga, and Ruttner, 1988), Central Saudi Arabia (Hepburn, 2005), around Aqaba in Jordan (Moritz et al., 2010; Haddad et al., 2008, 2009), 
Eilat in Israel (Moritz et al., 2010) and Djibouti in Africa (Steiner, 2017). However, in India's region, the red dwarf honey bee showed a steep decline in its colonies and foraging populations (Fig. 5 and 6). In 27 years, the colonies and the foraging populations were reduced to about 25 percent and this honey bee in this region seemed to head towards extirpation. The latter situation would lead to a likely significant loss of the pollination service to the region's natural and agro-ecosystems (Sihag, 1986, 2000, 2018, 2019a; Table 7).

The number of colonies and the foragers was highly positively correlated. This suggests that the reduction in populations was likely a result of fewer colonies. However, the reasons for such losses are not known. The causes and recourses of such declines need to be analyzed and worked out in the right perspectives so that suitable strategies could be applied to reverse the decline processes in colonies and foraging populations of this honey bee.

Like two other honey bees viz. the giant honey bee (Sihag, 2014) and the European honey bee (Sihag, 1991) the red dwarf honey bee too was free from any viral, bacterial, fungal, protozoan, and Acarine diseases in this region (Sihag, 2019b; Table 8). Parasitic mites and wax moths were also not the serious pests to cause total losses of this honey bee's colonies. There were no prominent predators, colony robbers or enemies to cause colony losses (Sihag, 2019b). Therefore, diseases and pests were not the likely causes of large-scale losses of the colonies and the foraging populations of this honey bee.

Table 8. Incidence of diseases, pests, predators, and enemies of the red dwarf honey bee (Apis florea) in the semiarid environment of northwest India (adapted from Sihag 2019b).

\begin{tabular}{|c|c|c|c|c|c|}
\hline \multirow{2}{*}{$\begin{array}{l}\text { Diseases, } \\
\text { pests, } \\
\text { predators, } \\
\text { and } \\
\text { enemies }\end{array}$} & \multicolumn{5}{|c|}{ Description of the pathogen/pest/enemy } \\
\hline & $\begin{array}{l}\text { Causal } \\
\text { organism } \\
\text { present/ } \\
\text { absent }\end{array}$ & $\begin{array}{l}\text { Month of } \\
\text { incidence/ } \\
\text { infestation }\end{array}$ & $\begin{array}{c}\text { Percent of } \\
\text { Colonies affected }\end{array}$ & $\begin{array}{l}\text { Kind of damage } \\
\text { to the colony }\end{array}$ & $\begin{array}{l}\text { Gravity of } \\
\text { damage } \\
\text { to the colony }\end{array}$ \\
\hline Viral disease & Absent & - & - & - & - \\
\hline $\begin{array}{l}\text { Bacterial } \\
\text { disease }\end{array}$ & Absent & - & - & - & - \\
\hline $\begin{array}{l}\text { Fungal } \\
\text { disease }\end{array}$ & Absent & - & - & - & - \\
\hline $\begin{array}{l}\text { Protozoan } \\
\text { disease }\end{array}$ & Absent & - & - & - & - \\
\hline $\begin{array}{l}\text { Acarine } \\
\text { disease }\end{array}$ & Absent & - & 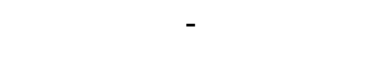 & - & - \\
\hline $\begin{array}{l}\text { Acarine } \\
\text { pest }\end{array}$ & $\begin{array}{l}\text { Euvarroa } \\
\text { sinhai } \\
\text { (present) }\end{array}$ & Feb-Mar & $\begin{array}{c}100 \% \text { of the over } \\
\text { wintering colonies ; and } \\
\text { about } 5 \% \text { of the new } \\
\text { colonies }\end{array}$ & $\begin{array}{l}\text { Perforated cap of } \\
\text { drone brood cell }\end{array}$ & No colony loss \\
\hline $\begin{array}{l}\text { Wax moth } \\
\text { pest }\end{array}$ & $\begin{array}{l}\text { Galleria } \\
\text { mellonella } \\
\text { (present) }\end{array}$ & Mar-Apr & $\begin{array}{c}100 \% \text { of over wintered } \\
\text { colonies; none of the new } \\
\text { colonies }\end{array}$ & $\begin{array}{l}\text { Destroy and } \\
\text { devour the } \\
\text { combs }\end{array}$ & $\begin{array}{l}\text { Combs in badly } \\
\text { damaged state } \\
\text { but no colony } \\
\text { loss }\end{array}$ \\
\hline $\begin{array}{l}\text { Predatory } \\
\text { wasps/ } \\
\text { birds }\end{array}$ & Absent & - & - & - & - \\
\hline $\begin{array}{l}\text { Other } \\
\text { enemies }\end{array}$ & Absent & - & - & - & - \\
\hline
\end{tabular}

-: incidence did not take place.

Degradation or loss of nesting area is considered one of the essential factors responsible for losing bee diversity (Sihag, 2013). In the present study area, there were plenty of nesting sites that could support hundreds of colonies of this honey bee. Therefore, loss of nesting area was unlikely to be the cause of the loss of colonies and foraging this honey bee's populations.

The study's place did have a floral dearth (Sihag, 1990) which staggered mid May through September. However, the red dwarf honey bee availed a year-round bee flora in the semi-arid environment of Northwest India (Table 7). Many crops like cucurbits, pearl millet, cotton and rice were in blooms during this period and acted as excellent pollen and nectar sources (Table 7) (Sihag, 2019a).Therefore, floral dearth was unlikely to be the cause of the decline of colonies and the foraging populations of the red dwarf honey bee.

Cotton and rice, the two major crops (grown in several thousand hectares) of this region, bear flowers during the dearth period. The cotton crop requires several sprays of contact and systemic insecticides to control insect pests (Plumer, 2014; Karen, 2018; Subhash et al., 2018). The use of insecticides on the cotton crop was started in the early 1980s; the region even witnessed these insecticides, aerial sprays. Pesticide usage is highest in Northwest India compared to the rest of the country, and cotton and rice are the major contributors (Alagh, 1988; Subhash et al., 2018). Due to the lack of alternate bee flora, the red dwarf honey bee had to visit the treated cotton crop (Table 8). All these pesticides have entirely changed the environment and ecology of the region (Fig. 7). The environment and habitat have become highly polluted and toxic for non-target indigenous organisms, including the red dwarf honey bee. These insecticides are highly toxic to this honey bee, and even their low doses become causes of their large-scale 
mortality (Sihag and Verma, 2001, 2002). The same situation prevails on the rice crop. The presence of insecticides in the honey bee's food chain seems to be the sole likely cause of the large-scale demise of colonies and the foraging bees. The primary loss seemed to be of the foraging bees on the treated crops. The sub-lethal doses of the insecticides brought to the nest might have caused severe mortality of the developing stages of this honey bee, ultimately resulting in loss of colony strengths and colony deaths. This likely cycle of loss of foragers and nest bees, and colony deaths seems to be going on year after year, leading to the present state of the red dwarf honey bee (Apis florea) being nearly extirpated from this region of India.

After cotton/rice, this region witnesses rich flowering on Raya (B. juncea), another major crop (Table 7; Sihag, 2019a). During its flowering period, the survived weak colonies of the red dwarf honey bee engage in brisk foraging, building, and reproductive activities, thus increasing their colony strength, colony numbers, and foraging populations. This may be the likely reason that the Carrot plots had significantly more foraging populations of the red dwarf honey bee than the Raya plots. However, the actual cause of this difference is needed to be investigated.

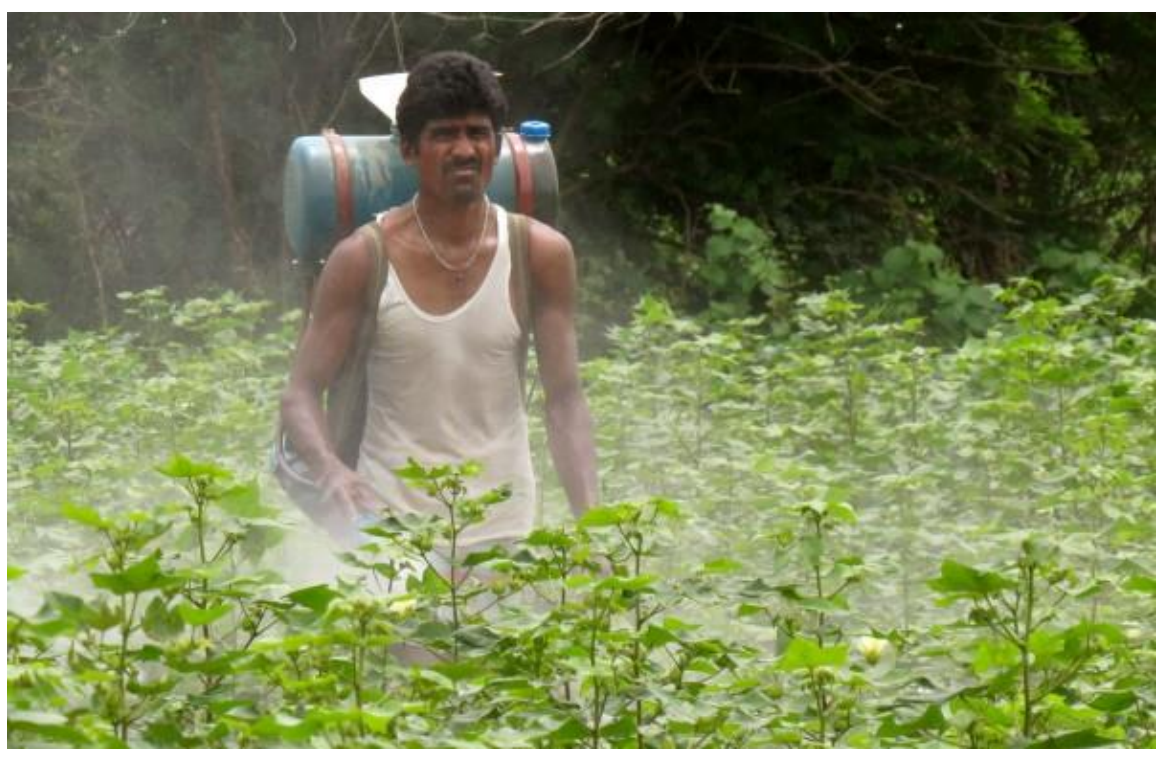

Fig. 7. A farmer spraying an insecticide on the cotton crop at the time of initiation of flowering (Source: https://gmandchemicalindustry9.files.wordpress.com/2015/09/cotton-spraying.jpg)

The massive losses of colonies and the foraging populations of the red dwarf honey bee sounds an alarm bell for the crop growers who have been receiving the free pollination service by this honey bee for their summer flowering crops in this region. This necessitates making immediate conservation efforts to save this honey bee from its complete extirpation from this region. Longterm honey bee conservation strategies will have to be devised and implemented to account for the application of integrated pest management practices in cotton and rice crops.

\section{Conclusion}

The red dwarf honey bee (Apis florea) is facing a severe decline in its colonies and the foraging populations in the semi-arid environments of Northwest India. Indiscriminate use of insecticides on cotton and rice crops seems to be the likely cause of declines in colonies and the foraging populations. Serious measures have to be taken to develop a crop protection strategy that may ensure a safe environment for this honey bee so that the latter could be saved from its extirpation from this region.

\section{Conflict of interest}

There was no conflict of interest during the study and in the publication of this research.

\section{Acknowledgements}

I am thankful to the Head, Department of Zoology for the general facilities, Heads, Department of Oilseeds Crops, and Vegetable Crops of CCS HAU, Hisar, for the crop facilities. I extend my thanks to all those who provided me assistance in the field and laboratory work during the long course of this study, especially members of my field staff Jhokhu Lal Yadav, Jagmal Singh, Dalbir Singh, Sarwan Kumar, Budhi Raja, and J.P. Narain Chaturvedi. R.N. Sheokand, a Statistician, helped me with the line drawings and data analysis. Helpful suggestions by G. Ottis on the earlier version of this article are gratefully acknowledged. This study was carried out under the long term projects "C(a) Zoo-2- Plan (Agri)", "C(a) Zoo-2- Non-Plan (Agri)" and "B(IV)-NP(Agri)" funded by the State Government of Haryana.

\section{References}

Alagh, Y. K., (1988). Pesticides in Indian Agriculture. Economic \& Political Weekly, 23 (38): 1959-1961+1963-1964.

Allen-Wardell, G., Bernhardt, P., Bitner, R. et al., (1998). The potential consequences of pollinator declines on the conservation of biodiversity and stability of food crop yields. Conserv. Biol. 12, 8-17.

Banaszak, J., (1992). Strategy for conservation of wild bees in an agricultural landscape. Agric. Ecosyst. Environ. 40, $179-192$.

Biesmeijer, J.C., Roberts, S.P.M., Reemer, M., Oholemuller, R., Edwards, M., Peeters, T., Schaffers, A.P., Potts, S.G., Kleukers, R., Thomas, C.D., et al., (2006). Parallel declines in pollinators and insect-pollinated plants in Britain and the Netherlands. Science 313 , 351-354. 
Brittain, C.A., Vighi, M., Bommarco, R. \& Settele, J., (2010). Impacts of a pesticide on pollinator species richness at different spatial scales. Basic Appl. Ecol. 11: 106-115. DOI: 10.1016/j.baae.2009.11.007

Breeze, T. D., Bailey, A.P., Balcombe, K.G. \& Potts, S.G., (2011). Pollination services in the UK: How important are honeybees? Agric. Ecosyst. Environ. 142, 137-143.

Burkle, L.A., Marlin, J.C. \& Knight, T.M., (2013). Plant-pollinator interactions over 120 Years: Loss of species, co-occurrence and function. Science, Pages:1-6. DOI:10.1126/science.1232728

Cameron, S.A., Lozier, J.D., Strang, J.P., Koch, J.B., Cordes, N., Solter, L.F. \& Griswold, T.L., (2011). Patterns of widespread decline in North American bumble bees. PNAS. 108 (20), 662-667. DOI: 10.1073/pnas.1014743108

Carvalheiro, L.G., Kunin, W.E., Keil, P, Aguirre-Gutiérrez, J., Ellis, W.N., Fox, R., Groom, Q., et al., (2013). Species richness declines and biotic homogenisation have slowed down for NW-European pollinators and plants. Ecol. Lett. 16, 870-878. DOI: https://doi.org/10.1111/ele.12121

Le Conte, Y. \& Navajas, M., (2008). Climate change: impact on honey bee populations and diseases. Rev. Sci. Tech. Off. Int. Epizoot. 27, 499-510.

Van Engelsdorp, D., Hayes Jr., J., Underwood, R.M. \& Pettis, J., (2008). A survey of honey bee colony losses in the U.S., Fall 2007 to Spring 2008. PLoS ONE 3, e4071. DOI:10.1371/journal.pone.0004071

Garibaldi, L.A., Steffan-Dewenter, I., Kremen, C., Morales, J.M., Bommarco, R., Cunningham, S.A., Carvalheiro, L. G., et al., (2011). Stability of pollination services decreases with isolation from natural areas despite honey bee visits. Ecol. Lett. 14, $1062-1072$.

Goulson, D., Lye, G.C. \& Darvill, B., (2008). Decline and conservation of bumble bees. Annu. Rev. Entomol. 53, $191-208$.

Goulson, D., Nicholls, E., Botías, C. \& Rotheray,E.L., (2015). Bee declines driven by combined stress from parasites, pesticides, and lack of flowers. Science 347, 1255957.

Grixti, J.C., Wong, L. T., Cameron, S. A. \& Favret, C., (2009). Decline of bumble bees (Bombus) in the North American Midwest. Biol. Conserv. 142, 75-84.

Haddad, N., de Miranda, J.R. \& Bataena, A., (2008). Discovery of Apis florea in Aqaba, Jordan. J. Apic. Res. 47 (2), $173-174$.

Haddad, N., Fuchs, S., Hepburn, H.R. \& Radloff, S.E., (2009). Apis florea in Jordan: Source of the founder population. Apidologie 40(4), 508-512.

Hegland, S.J., Nielsen, A., Lázaro, A. \& Bjerknes, Ø, (2009). How does climate warming affect plant-pollinator interactions?. Ecol. Lett. 12, 184-195.

Hepburn, H.R. \& Radloff, S.E. (Ed.)., (2011). Honey bees of Asia. Springer. Heidelberg, London, New York.

Hepburn, H.R., Radloff, S. E., Otis, G.W., Fuchs, S., Verma, L. R., Ken, T., ... Wongsiri, S., (2005). Apis florea: Morphometrics, classification and biogeography. Apidologie 36(3), 359-376.

Johnson, R. (2007). Recent Honey Bee Declines. Congressional Research Service, Washington, DC: 14 pages.

Karen, (2018). Insecticides, pesticides and honey bees. Insect Cop.net. July 16, 2018. https://insectcop.net/insecticide-pesticidesand-honeybees/

Kearns, C.A., Inouye, D.W. \& Waser, N.M., (1998). Endangered mutualisms: the conservation of plant-pollinator interactions. Annu. Rev. Ecol. Syst. 29, 83-112.

Kevan, P.G., (1975). Forest application of the insecticide Fenitrothion and its effects on wild bee pollinators (Hymenoptera: Apoidea) of lowbush blueberries (Vaccinium spp.) in southern New Brunswick, Canada. Biol. Conserv. 7, 301-309.

Klein, A-M., Vaissière, .., Cane, J.H., et al. (2007). Importance of pollinators in changing landscapes for world crops. P. Roy. Soc. Lond. B Bio. 274, 303-313.

Kluser, S. \& Peduzzi, P., (2007). Global pollinator decline: a literature review. Geneva: UNEP/GRID.

Kraus, B. \& Page, R.E., (1995). Effect of Varroa jacobsoni (Mesostigmata: Varroidae) on feral Apis mellifera (Hymenoptera: Apidae) in California. Environ. Entomol. 24, 1473-1480.

Kremen, C. \& Ricketts, T., (2000). Global perspectives on pollination disruptions. Conserv. Biol. 14, 1226-1228.

Kremen, C., Williams, N.M. \& Thorp, R.W., (2002). Crop pollination from native bees at risk from agricultural intensification. P. Natl. Acad. Sci., USA. 99, 16812-16816.

Kremen, C., Williams, N.M., Bugg, R.L., Fay, J.P. \& Thorp, R.W., (2004). The area requirements of an ecosystem service: crop pollination by native bee communities in California. Ecol. Lett. 7, 1109-1119.

Lakshmi Priya, S., (2017). No pesticides yet bountiful cotton crop-the secret of farmers in Haryana and Punjab. The Better India.com. October 19, 2017. https://www.thebetterindia.com/118700/no-pesticides-yet-bountiful-cotton-crops-secret-of-farmersin-haryana-punjab/

Mogga, G.B. \& Ruttner, F., (1998). Apis florea in Africa: Source of the founder population. Bee Wld. 69(3), 100-103. DOI: http://dx.doi.org/10.1080/0005772X.1988.11098960

Moradi, M.G. \& Kandemir, I., (2005). Observations on Apis florea "the red dwarf honey bee" in Iran. Amer. Bee J. 145, 498-502.

Moritz, R.F.A., Haddad, N., Bataieneh, A., Shalmon, B. \& Hefetz, A., (2010). Invasion of the red dwarf honey bee, Apis florea into the near East. Biol. Invas. 12, 1093-1099.

National Research Council, (2007). Status of Pollinators in North America. The National Academies Press, Washington, DC.

Neumann, P. \& Carreck, C., (2010). Honey bee colony losses: a global perspective. J. Apic. Res. 49, 1-6.

Oldroyd, B.P., (2007). What's killing American honey bees? Plos Biol. 5, 1195-1199.

Oldroyd, B.P. and Wongsiri, S. (2006). Asian Honey Bees: Biology, Conservation and Human Interactions. Harvard University Press, Cambridge, Massachusetts.

OPSTAT, (2018a). https://www.hau.ac.in/page/o-p-stat

OPSTAT, (2018b). http://14.139.232.166/opstat/onefactor.htm?flavor=One+Factor+Analysis

OPSTAT, (2018c). http://14.139.232.166/opstat/twofactor.html?flavor=Two+Factors+Analysis

Otis, G.W., (1996). Distribution of recently recognized species of honey bees (Hymenoptera: Apidae: Apis) in Asia. J. Kansas Entomol. Soc. 69: 311-333.

Pauw, A., (2007). Collapse of a pollination web in small conservation areas. Ecology 88, 1759-1769.

Plumer, B., (2014). Are pesticides killing all the honey bees? It's complicated. Vox. May 23, 2014. https://www.vox.com/2014/5/23/5742398/are-pesticides-killing-the-honeybees-its-complicated

Potts, S.G., Biesmeijer, J.C., Kremen, C., et al., 2010a. Global pollinator declines: trends, impacts and drivers. Trends Ecol. Evol. 25, 345-353. DOI: https://doi.org/10.1626/j.tree.2010.01.007 
Potts, S.G., Roberts, S.P.M., Dean, R., Marris, G., Brown, M.A. \& Jones, R., (2010b). Declines of managed honeybees and beekeepers in Europe. J. Apic. Res. 49, 15-22.

Powney, G.D., Carvell, C., Edwards, M., Roger, K.A., Morris, R.K.A., Roy, H.E., Woodcock, B.A. \& Isaac, N.B.J., (2019). Widespred losses of pollinating insects in Britain. Nature Communications 10, Article number: 1018. DOI: https://doi.org/10.1038/s41467-01908974-9

Richards, A.J., (2001). Does low biodiversity resulting from modern agricultural practice affect crop pollination and yield? Annals of Botany $88,165-172$.

Ruttner, F., (1988). Biogeography and taxonomy of honey bees. Berlin, Heildelberg: Springer-Verlag.

Schneider, S.S., DeGrandi-Hoffman, G. \& Smith, D.R., (2004). The African honey bee: factors contributing to a successful biological invasion. Annu. Rev. Entomol. 49, 351-376.

Sihag, R.C., (1986). Insect pollination increases seed production in cruciferous and umbelliferous crops. J. Apic. Res. 25 (2), 121 126.

Sihag, R.C., (1990). Ecology of European honey bee (Apis mellifera L.) in semi-arid sub-tropical climates.1. Melliferous flora and over-seasoning of the colonies. Korean J. Apic. 5 (1) 31-43.

Sihag, R.C., (1991). Ecology of European honey bee (Apis mellifera L.) in semi-arid sub-tropical climates. 2. Seasonal incidence of diseases, pests, predators and enemies. Korean J. Apic. 6 (1), 16-26.

Sihag, R.C., (2000). Eco-biology of the little honeybee (Apis florea F.) in semi-arid sub-tropical climates of India In: Asian Bees and Beekeeping: Progress of Research and Development, (Eds.: M. Matsuka et al.). Oxford \& IBH Publ. Co. Pvt Ltd. New Delhi, pp: 4649.

Sihag, R.C., (2001). Why should beekeeping be utilized as an input in agriculture? Current Sci. 81 (12), $1514-1516$.

Sihag, R.C., (2013). Bee diversity for floral diversity. In: Nature Science, by M.R. Islam (Ed.). Nova Science Publishers Inc. pp: 273278.

Sihag, R.C., (2014). Phenology of migration and decline in colony numbers and crop hosts of giant honeybee (Apis dorsata F.) in semi-arid environment of Northwest India. J. Insects 1-9, Article ID 639467, DOI: http://dx.doi.org/10.1155/2014/639467

Sihag, R. C., (2018). Some unresolved issues of measuring the efficiency of pollinators: experimentally testing and assessing the predictive power of different methods. Internl. J. Ecol. 2018, 1-13. Article ID 3904973, DOI: https://doi.org/10.1155/2018/3904973

Sihag, R.C., (2019a). Crop hosts and pollination potential of the red dwarf honey bee (Apis florea F.) in the semi-arid environment of Northwest India. J. Appl. Sci. 19, 551-556. DOI: 10.3923/jas.2019.551-556

Sihag, R.C., (2019b). How serious is the threat of diseases and pests to the red dwarf honey bee (Apis florea F.)? J. Appl. Sci. 19 (5), 376-383. DOI: 10.3923/jas.2019.376-383

Sihag, R.C. \& Verma, S., (2001). Acute contact and stomach toxicity of endosulfan and carbaryl insecticides to the little honeybee, Apis florea F. Asian Bee J. 3, 13-19.

Sihag, R.C. \& Verma, S., (2002). Acute contact and stomach toxicity of five organophosphate insecticides to the little honeybee, Apis florea F. Asian Bee J. 4, 13-18.

Snedecor, G.W. \& Cochran, W.G., (1967). Statistical Methods (6th Edn.). Oxford and IBH Publishing Co. Pvt. Ltd., New Delhi, 593p.

Steffan-Dewenter, I., Munzenberg, U., Burger, C., Thies, C. \& Tscharntke, T., (2002). Scale-dependent effects of landscape structure on three pollinator guilds. Ecology 83, 1421-1432.

Steffan-Dewenter, I., Potts, S.G. \& Packer, L., (2005).Pollinator diversity and crop pollination services are at risk. Trends Ecol. Evol. 20, 651-652.

Steiner, W.E., (2017). A scientific note on the arrival of the red dwarf honey bee, Apis florea (Hymenoptera: Apidae), in Djibouti. Apidologie. DOI: http://dx.doi.org/10.1007/s13592-017-0511-9

Subhash, S.P., Chand, P., Pavithra, S., Balaji, S.J. \& Pal, S., (2017). Pesticide use in Indian agriculture: Trends, market structure and policy issues. National Center for Agricultural Economics and Policy Research, ICAR, New Delhi, Technical Report \# 43, pp: 1-5.

Tonhasca, A., Blackmer, J. \& Albuquerque, G.S., (2002). Abundance and diversity of euglossine bees in the fragmented landscape of the Brazilian Atlantic forest. Biotropica 34, 416-422. DOI: 10.1111/j.1744-7429.2002.tb00555.x

Toppo, A., (2019). Management and control of sucking pests and white fly in cotton. https://krishijagran.com/agripedia/management-and-control-of-sucking-pests-and-white-fly-in-cotton/

Vanbergen, A. J., (2013). Threats to an ecosystem service: pressures on pollinators. Frontiers Ecol. Environ. 11(5), 251-259. DOI: https://doi.org/10.1890/120126

Westerkamp, C. \& Gottsberger, G., (2002). The costly crop pollination crisis. In: Pollinating bees - The conservation link between agriculture and nature (Kevan P, Imperatriz Fonseca V, eds.). Brasilia Ministry of Environment, 51-56.

Williams, P.H. \& Osborne, J.L., (2009). Bumble bee vulnerability and conservation world-wide. Apidologie 40, 367-387.

\section{Citation:}

Sihag, R.C. (2021). The red dwarf honey bee (Apis florea F.) faces the threat of extirpation in Northwest India Ukrainian Journal of Ecology, 11 (2), 1-11, Ecological Risk Assessment. 